\title{
EDITORIAL
}

\section{UNETHICAL AND UNAUTHORIZED MEDICAL PRACTICE- AN ALARMING SITUATION}

Bangladesh is a land of vast population which is nearly 15 crore. At present there are approximately 40000 registered physicians working in both public and private sector. But this is a very meager in the context of population. In our country the DoctorPatient relation is about1:4719 ${ }^{1}$. We have only 25 specialized hospitals and 6 post graduate hospital. The number of total hospital bed is 40,773 in which over 29000 belong to government hospital ${ }^{1}$. It is very difficult to give quality service to all with this strength of doctors. That's why in early eighties the necessity of Paramedics or 'Pollychikitshok' was felt to help the medical graduates in the primary level hospital and also to provide primary health care to the rural people. Subsequently a post was created in the Union and Upazilla health complex namely Sub assistant Community Medical Officer (SACMO).

In our country $77 \%$ people still live in the rural $\operatorname{areas}^{1}$. So the Rural people are a great concern for our Health system. For lack of registered doctors, most of the villagers depend upon the quack and paramedics (Polly chikitshok) including Sub assistant Community Medical Officer (SACMO) whose main work is to assist the doctor and to give primary advice to the patients. They are given requisite training for the same. It is undenial that paramedics or Polly chikitshok are the part and parcel of our health system. It is also true that many of them are giving dedicated service for the ill fitted patients but a large number of them are engaged in unethical and illegal practice by prescribing medicine which is not entitled. Even some of them are using "Doctor" in their names. It is very much harmful for our health sector.

It is obvious that they are not the substitute of doctors rather they are the helping hand. it is seen that they posed themselves as full fledged practitioner. This is absolute breach of Bangladesh Medical and Dental Council (BMDC) rules and regulation as we know that no body can practice without the registration of BMDC. These quack and paramedics prescribe many nameless medicines to the villagers and by taking this low quality medicine the villagers are facing many adverse drug related problems ${ }^{2}$.

Moreover sometime they frequently use many valuable drugs in incomplete dose and in improper way. We routinely receive many patients in the secondary and tertiary level hospital who has already got antibiotics like third generation Cephalosporin, Imipenem etc, anti-hypertensives etc. and sometime even Anti viral drugs. Government has to take strong regulatory steps regarding control of this quack and paramedic's.We think government should make a specific list of drugs for the paramedics. They cannot use any drugs beyond this list and it must be monitored by a proper body ${ }^{2,3}$. If we can implement this law properly we surely can control the mal practice of both the unregistered practitioner and pharmaceutical companies. If we can limit the use of drug by these paramedics, automatically pharmaceutical company will not go to the paramedics for their promotional activities.

Recently another new thing is emerging in Bangladesh. Some medical related Bachelor Degree holders also begin to practice like Physiotherapist, Pchychotherapist etc.In fact they are the technical hands who can give suggestion to the patient but are not entitled to prescribe medicine. In many cases they are using "Doctor" in their names. This is also a breach of law which should be monitored strictly by the appropriate authority.

In the periphery it is sometime found that paramedics and village quack are doing operation 
like caesarean section, appendicectomy etc. for making profit. This is also suicidal to the nation. The Government has to be very strict to combat this mal practice.

Fazle Rabbi Chowdhury ${ }^{1}$, Md. Billal Alam ${ }^{2}$ ${ }^{1}$ Post Graduate Trainee, Department of Medicine, Dhaka Medical College, ${ }^{2}$ Associate Professor of Medicine, Dhaka Medical College.

\section{References:}

1. Ministry of health and family welfare: National Health Policy, enacted by Government of People's Republic of Bangladesh. Available on http:// www.mohfw.gov.bd/. Accessed December 13, 2007.

2. Chowdhury FR, Chowdhury MA, Chowdhury S.Quality, Safety and Efficacy of Drug in Bangladesh: Where We Are.J Medicine 2005; 6:55-8.

3. Chowdhury FR, Ahasan HAMN, Rahman MM.National Drug Policy of Bangladesh: Some pitfalls on implementation. J Coll Physicians Surg Pak 2006; 16:368-70. 